\title{
Poles in North America Conference
}

\author{
John Bodnar \\ Pennsylvania Historical and Museum Collection
}

The Multicultural History Society of Ontario sponsored an international conference on the Poles in North America from October 23rd to 25th, 1980, in Toronto. The conference was broad based and not easily summarized, for it dealt with a number of important subject areas and issues in the study of this particular ethnic group. Collectively, however, the various sessions brought together an array of scholarly viewpoints. When the conference papers are published by the Multicultural History Society in early 1982, the collection should not only represent a valuable addition to the literature on this group but contain perhaps the most informative accounts of Poles in this hemisphere since the publication of William Thomas and Florian Znaniecki, The Polish Peasant in Europe and America (1920).

Discussion and debate centered around seven major, thematic areas. Scholars from the Academy of Sciences in Warsaw provided good social and economic data on Polish emigration and a profile of those who were leaving. "Work and Enterprise" formed the basis for a second session with a number of papers relevant to labor historians including "Poles in Johnstown, Pennsylvania" by E. Morawska (History, Carnegie-Mellon University), "Polish Workers of Chicago"s South Side," by D. Pacyga (1645 E. 50th St., Chicago, Ill.), and an essay on Detroit Poles and the struggle for jobs and housing by T. Radzialowski (History, Southwest Minnesota State University). The session on "Secular Institutions" was highlighted by a paper on Polish fraternals by D. Pienkos (University of Wisconsin, Milwaukee) and a roundtable discussion on "Polishness" probed the real but often nebulous nature of ethnic identity. Historians interested in religion and the working class would benefit most from L. Chrobot's paper on the sociological functions of religion among Polish-Americans which highlighted the session on the "Role of Churches." Reverend Chrobot can be reached at St. Mary"s College, Orchard Lake, Michigan. The "Urban Experience" examined the urban structure as a generator of ethnic identity. Important was the work of E. Obidinski (SUNY, Oneonta). Finally, a panel on the Polish family explored a number of topics including intergenerational relations (H. Lopata. Loyola Univ., Chicago), immigrant families and the industrial economy (J. Bodnar), and important census data analysis on women from J. Parot (History, Northern Illinois University). 
If copies of any of the papers are needed before publication, they can he obtained by writing the individual speakers directly. Multicultural History Society of Ontario, 43 Queen`s Park Crescent East, Toronto, Ontario, M5S2C3. 